International Journal of Business Management and Economic Review

Vol. 4, No. 04; 2021

ISSN: 2581-4664

\title{
THE EFFECT OF JOB CRAFTING ON WORK PERFORMANCE OF LAN RI MEDIATED BY WORK ENGAGEMENT AND JOB SATISFACTION
}

\author{
*Syahrul, Abdul Rahman Lubis, Nurdasila \\ Management Department, Universitas Syiah Kuala, Indonesia \\ http://doi.org/10.35409/IJBMER.2021.3307
}

\begin{abstract}
This study aims to examine the effect of job crafting on work performance that is respectively mediated by work engagement and job satisfaction on The National Institute of Public Administration of the Republic of Indonesia (LAN RI) employees. The research population was the LAN RI employees, totaling 1.007 employees throughout Indonesia. There were 286 employees chosen as the sample through the Slovin method. Data were analyzed by Structural Equation Modelling (SEM) Analysis of Moment Structures (AMOS). From the result and analysis, we can conclude that job crafting affects work engagement, job crafting affects job satisfaction, job crafting affects work performance, job crafting affects work performance through work engagement, and job crafting affects work performance through job satisfaction. Work engagement and job satisfaction act as partial mediators in the model. These findings, academically illustrate that the model studied has been tested and verified, that for models of improving work performance, the function of increasing job crafting is very necessary to be carried out, so that it can affect work engagement and job satisfaction which will result in increased work performance. This finding has implications for the realm of science management so that further researchers can develop this tested work performance improvement model by adding new variables such as talent management and innovative culture.
\end{abstract}

Keyword: Job Crafting, Work Engagement, Job Satisfaction, Work Performance.

\section{INTRODUCTION}

The National Institute of Public Administration of the Republic of Indonesia (LAN RI) is a nonministerial government institution that has duties in the field of state administration regarding the provision of applicable laws and regulations. The establishment of LAN RI is based on a design drawn up by the Planning Committee for the Establishment of an Educational Institution for Government Administration Staff which was formed by the Minister of Education, Teaching, and Culture with the task of making a complete and concrete plan on the establishment of an institute for the education government administrative personnel, for the presence of capable and skilled government officials in the state administration system following the form of an independent state. As an institution that carries out government duties in the field of state administration, quality human resources are needed so they can work to meet the expectations of the organization. 


\section{International Journal of Business Management and Economic Review}

Vol. 4, No. 04; 2021

ISSN: 2581-4664

As for employees' performance, (Agusniwar, Azis, \& Darsono, 2017) said that the achievement of someone in his job is following the established criteria. However, (Albana, 2019) entitled "The Effect of Job Crafting and Work Engagement toward Employees' Performance at PT. Terminal Teluk Lamong" claimed that job crafting does not affect employees' performance, rather it affects work engagement, while work engagement affects employees' performance. In this study, work engagement mediates the relationship between job crafting and work performance.

Nowadays, in work performance embodiment, work engagement is quite fundamental for employees to have. According to (Schaufeli, Bakker, \& Salanova, 2006), work engagement is the positivity of work fulfillment from the center of a person's characterized mind. In line with this, a study of work engagement on work performance has been conducted (Qodariah, 2019) toward 120 chiefs of

PT. Surveyor Indonesia. She explains that work engagement has a direct and positive effect on employee performance. Meanwhile, a study called "The Effect of Work Engagement on Employee Performance at Atria Hotel Malang through Organizational Citizenship Behavior as a Mediation Variable" concludes that work engagement has a positive and significant effect on employees' performance.

LAN RI in its process always tries to maximize its services. According to (Newstrom \& Davis, 2002), giving their best performance in order to bring such job contentment is a set of employees' feelings about whether their job is pleasant or unpleasant. Research on job satisfaction toward work performance was conducted by (Wijaya, 2018) on 73 employees of PT Bukit Sanomas. The writer states that employees' job satisfaction had an impact on employees' performance. The same research was also conducted by (Damayanti, Hanafi, \& Cahyadi, 2018) on 40 respondents. She stated that there was a strong and significant effect of job satisfaction on work performance in Siti Khadijah Islamic Hospital Palembang, South Sumatra.

Organizations will always make an adjustment to changes thus the role of employees who have high initiative and creativity will become helpful. Job crafting is considered as a self-initiative behavior that focuses on employees perceiving the environment and acting upon their preferences, values, and abilities, not just doing the work that has been assigned by the organization (Tims, Bakker, \& Derks, 2013). Research on the effect of job crafting on work performance was also proven by (Hooff, 2016) who researched 117 HRD employees, concluding that job crafting had a significant and positive effect on employee performance. (Wingerden \& Poell, 2017) conducted a study on 2,090 heterogeneous employees in the Netherlands. Their research mentions that job crafting has a significant and positive effect on performance. Conversely, the facts that were found in the research conducted by (Petrou, Demerouti, \& Schaufeli, 2015) on 580 police officers stated job crafting has no significant effect on employee performance.

Based on the explanations above, the authors were encouraged to conduct a research entitled "The Effect of Job Crafting on Work Performance that is Respectively Mediated by Work Engagement and Job Satisfaction on the LAN RI".

\section{LITERATURE REVIEW Performance}


Performance means how well a person does their job. (Robbins \& Judge, 2017) defines performance as employees' achievement that fits with certain criteria applied in their job. Performance is the result of work or activity which contains three aspects: clarity of responsible tasks, clarity of expected results from a job or function, and clarity of time needed to complete work so that the expected results can be achieved.

Based on the various opinions above, it can be interpreted that performance is how competence a person does a job and as a result of work that has been done by a worker in order to achieve the goals of a company or organization to minimize losses. Performance indicators according to (Gomes, 2003) are:

1. Work Quantity

2. Quality of Work

3. Work Knowledge

4. Creativity

5. Cooperation

6. Trustworthy

7. Initiative

8. Personal Qualities

\section{Work Engagement}

(Perrin, 2003) provides an understanding of work engagement as a center of self-affective that reflects employee's personal satisfaction and the affirmation they get from working and being part of an organization. (Saks, 2006) explained that work engagement is a construct that applies cognitive, emotional, and behavioral components related to work responsibilities.

From those opinions above, the researcher concludes that work engagement is the attitude and behavior of employees in carrying out their roles in work by expressing themselves fully, physically, cognitively, affectively, and emotionally. Employees will work harder and try something for the job beyond what is expected both in time and energy, which is specified by passion, dedication, and absorption. According to (Schaufeli et al., 2006), indicators of work engagement are:

1. Being passionate in doing the job

2. refuse to give up easily

3. Taking pride in doing a complete job

4. $\quad$ Giving full devotion to one particular job

5. $\quad$ Feeling attached to work

6. $\quad$ Focusing at work

\section{Job Satisfaction}

(Hughes, Ginnett, Curphy, \& Izzati, 2012) says that job satisfaction is related to one's feelings or attitudes about the work itself; salary, promotion or education opportunities, supervision, coworkers, workload, and others. In this case, what is meant by the attitude is related to supervision control, salary, work condition, experienced skills, fair and non-adverse assessment, good social relations, quick response to complaints, and good treatment from the leaders toward employees. According to (Robbins \& Judge, 2017), job satisfaction is a positive feeling about one's work which is the result of evaluating one's characteristics. (Wagner \& Hollenbeck, 2015) claimed 
that job satisfaction is a feeling of contentment or a positive emotion toward the results of a job or work experience. Work satisfaction is a common attitude toward a person's work, indicating the difference between the number of awards they have received to which they believe they should receive. (Luthans, 2013) suggested that job satisfaction indicators include the following:

1. Comfortable working atmosphere

2. Sufficient work equipment

3. Balanced salary/benefits

4. Skillful (creative)

5. Promotional opportunity (career)

6. Co-workers association

\section{Job Crafting}

Job crafting is actualized as a form of change made by employees, both physically and cognitively, to proactively shape work experiences and be active in responding to the work environment (Kuijpers, Kooij, \& Woerkom, 2019). According to Slemp and Brodrick (2018), job crafting is a way in which employees have an active role by making changes both physically and cognitively.

Based on some explanation of the experts, it can be concluded that job crafting is a proactive step and action to redesign what we do at work. Job crafting is also a change in work behavior on one's initiative to make employees feel bound by the goal to align work with preferences, motives, and passions. Job crafting indicators according to (Tims et al., 2013) are as follows:

1. Developing competencies

2. New skills

3. Avoiding difficult decision-making

4. Suggestion and input from colleagues

5. Opportunity to do new jobs

6. Doing challenging job

\section{Research Framework and Hypothesis}

The research framework and hypothesis formulated in this study are as follows:

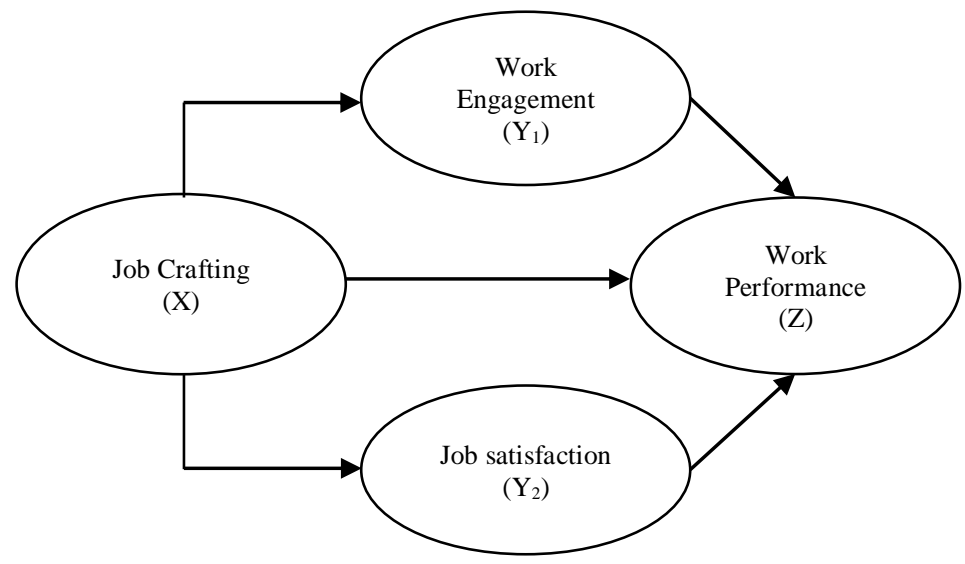


International Journal of Business Management and Economic Review

Vol. 4, No. 04; 2021

ISSN: 2581-4664

Figure 1. Research Framework

The hypothesis formulated in this study are as follows:

H1 : $\quad$ job crafting affects work engagement

H2 : $\quad$ job crafting affects job satisfaction

H3 : $\quad$ job crafting affects work performance

H4 : $\quad$ job crafting affects work performance through work engagement

H5 : $\quad$ job crafting affects work performance through job satisfaction

\section{RESEARCH METHOD}

Population and sample

The population of this research was on LAN RI employees involving 1.007 employees throughout Indonesia. To select the sample, the researcher took a minimum sample with the Slovin formula. So there were 286 employees as the sample. The samples from each working unit on the LAN RI are elaborated in the following table based on the proportional allocation formula.

Table 1. Research Population and Sample

\begin{tabular}{|c|l|c|c|c|}
\hline No & \multicolumn{1}{|c|}{ Work Unit } & Total Population & Total sample & Percentage \\
\hline 1. & LAN Jakarta & 480 & 136 & $47.67 \%$ \\
\hline 2. & Puslatbang PKASN & 104 & 30 & $10.33 \%$ \\
\hline 3. & Puslatbang KMP & 74 & 21 & $7.35 \%$ \\
\hline 4. & Puslatbang KDOD & 53 & 15 & $5.26 \%$ \\
\hline 5. & Puslatbang KHAN & 61 & 17 & $6.06 \%$ \\
\hline 6. & Politeknik STIA LAN Jakarta & 78 & 22 & $7.75 \%$ \\
\hline 7. & Politeknik STIA LAN Bandung & 85 & 24 & $8.44 \%$ \\
\hline 8. & Politeknik STIA LAN Makassar & 72 & 21 & $7.15 \%$ \\
\hline \multicolumn{2}{r|}{ Total } & $\mathbf{1 . 0 0 7}$ & $\mathbf{2 8 6}$ & $\mathbf{1 0 0 \%}$ \\
\hline
\end{tabular}

Source: SDM LAN RI (2020)

Sources and Data Collection Technique

The data have been collected through a personal questionnaire. This method provided good responses to the questionnaire. In this study, questionnaires were distributed through a google form application to respondents and the WhatsApp group of each regional office of the LAN RI. The respondents were asked to choose one of the alternative answers that the researcher had provided in the google form application.

Operational Variable

There are two variables used in this study; the independent variable which is job crafting (X), and the dependent variables which are work engagement (Y1) and work satisfaction (Y2), and work performance $(\mathrm{Z})$ as described in the following table. 
International Journal of Business Management and Economic Review

Vol. 4, No. 04; 2021

ISSN: 2581-4664

\section{Table 2. Research Operational Variable}

\begin{tabular}{|c|c|c|c|}
\hline No & Variable & Definition & Indicator \\
\hline \multicolumn{4}{|c|}{ Exogenous Variable } \\
\hline 1. & $\begin{array}{l}\text { Job Crafting } \\
(\mathrm{X})\end{array}$ & $\begin{array}{l}\text { Job crafting can be defined as } \\
\text { making self-initiative changes to } \\
\text { balance job requirements and } \\
\text { resources (Tims et.al., 2012) }\end{array}$ & $\begin{array}{l}\text { - Developing competencies } \\
\text { - New skills } \\
\text { - Avoiding difficult decision-making } \\
\text { - Suggestion and input from colleagues } \\
\text { - Opportunity to do new jobs } \\
\text { - Doing challenging job } \\
\text { (Tims et al., 2013) }\end{array}$ \\
\hline \multicolumn{4}{|c|}{ Intervening Variable } \\
\hline 2. & $\begin{array}{l}\text { Work } \\
\text { Engagement } \\
\left(\mathrm{Y}_{1}\right)\end{array}$ & $\begin{array}{l}\text { Illusory power (commitment to the } \\
\text { organization, pride, effort, } \\
\text { dedication, passion, and interest in } \\
\text { work) that motivates employees to } \\
\text { advance their work. Albrecht, S. L. } \\
\text { (2016) }\end{array}$ & $\begin{array}{l}\text { - Being passionate in doing the job } \\
\text { - refuse to give up easily } \\
\text { - Taking pride in doing a complete job } \\
\text { - Giving full devotion to one particular job } \\
\text { - Feeling attached to work } \\
\text { - Focusing at work } \\
\text { (Schaufeli et al., 2006) }\end{array}$ \\
\hline 3. & $\begin{array}{l}\text { Work } \\
\text { Satisfaction } \\
\left(\mathrm{Y}_{2}\right)\end{array}$ & $\begin{array}{l}\text { Good or Bad emotional condition by } \\
\text { which employees see their job } \\
\text { outcomes } \\
\text { Luthans (2017) }\end{array}$ & $\begin{array}{l}\text { - Comfortable working atmosphere } \\
\text { - Sufficient work equipment } \\
\text { - Balanced salary/benefits } \\
\text { - Skillful (creative) } \\
\text { - Promotional opportunity (career) } \\
\text { - Co-workers association } \\
\text { (Luthans, 2013) }\end{array}$ \\
\hline \multicolumn{4}{|c|}{ Endogenous Variable } \\
\hline 4. & $\begin{array}{l}\text { Work } \\
\text { Performance } \\
(\mathrm{Z})\end{array}$ & $\begin{array}{l}\text { Work outcomes from individuals or } \\
\text { functions of certain jobs or } \\
\text { professions. } \\
\text { Robbins }(2015)\end{array}$ & $\begin{array}{l}\text { - Work Quantity } \\
\text { - Quality of Work } \\
\text { - Work Knowledge } \\
\text { - Creativity } \\
\text { - Cooperation } \\
\text { - Trustworthy } \\
\text { - Initiative } \\
\text { - Personal Qualities } \\
\text { (Gomes, 2003) }\end{array}$ \\
\hline
\end{tabular}

Intervening Variable

2. Work Engagement (Y1) Illusory power (commitment to the organization, pride, effort, dedication, passion, and interest in work) that motivates employees to advance their work. Albrecht, S. L. (2016) • B Being passionate in doing the job

- $\quad$ refuse to give up easily

- $\quad$ Taking pride in doing a complete job

- $\quad$ Giving full devotion to one particular job

- $\quad$ Feeling attached to work 
International Journal of Business Management and Economic Review

Vol. 4, No. 04; 2021

ISSN: 2581-4664

- $\quad$ Focusing at work

(Schaufeli et al., 2006)

3. Work Satisfaction (Y2) Good or Bad emotional condition by which employees see their job outcomes

Luthans (2017) - C Comfortable working atmosphere

- $\quad$ Sufficient work equipment

- $\quad$ Balanced salary/benefits

- $\quad$ Skillful (creative)

- $\quad$ Promotional opportunity (career)

- $\quad$ Co-workers association

(Luthans, 2013)

Endogenous Variable

4. Work Performance (Z) Work outcomes from individuals or functions of certain jobs or professions.

Robbins (2015) • W Work Quantity

- $\quad$ Quality of Work

- Work Knowledge

- Creativity

- Cooperation

- Trustworthy

- Initiative

- $\quad$ Personal Qualities

(Gomes, 2003)

\section{DATA ANALYSIS}

\section{Structural Model Measurement}

The data analysis technique used in this study is a Structural Equation Model (SEM) with the help of the Statistical Package for the Social Science Analysis of Moment Structures (SPSSAMOS-22) software. The researcher used SEM because the study development model has paths that connect exogenous variable to endogenous variables. The exogenous variable is job crafting, and the endogenous variables are work engagement, job satisfaction, and work performance. 


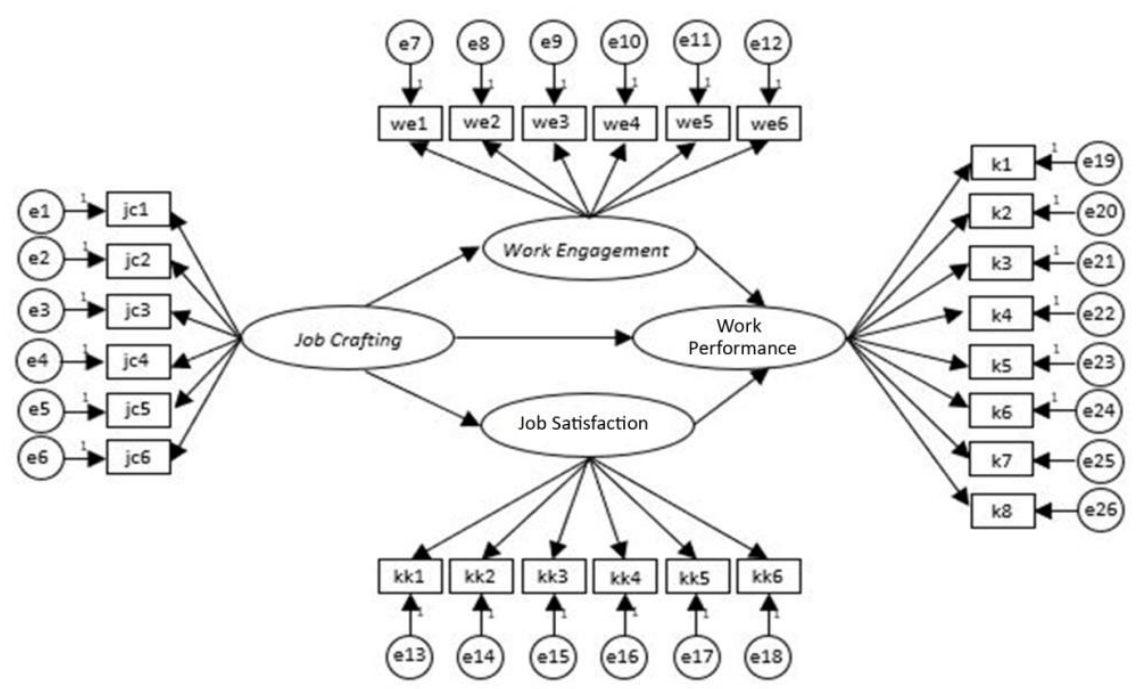

Figure 2. Structural Equation Modelling (SEM) Analysis

Based on the figure above, the research model can be concluded as follows:

Job Crafting $=\quad \gamma 11$ Work Engagement $+\gamma 12$ Work Satisfaction $+\zeta 1$

Work Performance $\quad=\quad \gamma 21$ Work Engagement $+\gamma 22$ Work Satisfaction $+\beta 21$ Job Crafting $+\zeta 2$

There are two ways to test the hypothesis, direct effect testing and indirect effect testing with work engagement and job satisfaction as intervening variables. The concept of testing the indirect effect used the model developed by (Baron \& Kenny, 1986).

\section{RESULT AND DISCUSSION}

Respondent Characteristics

The Respondent Characteristics from the data collection can be seen in the following table.

Table 3. Respondents' Characteristics

\begin{tabular}{|l|l|l|c|}
\hline No & \multicolumn{1}{|c|}{ Characteristic } & \multicolumn{1}{c|}{ Frequency } & Percentage \\
\hline \multirow{3}{*}{1.} & Gender & 165 & 57.7 \\
\cline { 2 - 4 } & Male & 121 & 42.3 \\
\cline { 2 - 4 } & Female & $\mathbf{2 8 6}$ & $\mathbf{1 0 0}$ \\
\hline \multirow{2}{*}{ TOTAL } & 2 & 0.7 \\
\hline \multirow{4}{*}{2.} & Age & 30.8 \\
\cline { 2 - 4 } & $<20$ Years old & 88 & 40.9 \\
\cline { 2 - 4 } & 20-29 Years old & 117 & 27.6 \\
\cline { 2 - 4 } & 30-39 Years old & 79 & $\mathbf{1 0 0}$ \\
\cline { 2 - 4 } & $>39$ Years old & $\mathbf{2 8 6}$ & 66.1 \\
\hline \multicolumn{2}{|l|}{ TOTAL } & 189 & \\
\hline \multirow{2}{*}{3.} & Marital Status & Single &
\end{tabular}


International Journal of Business Management and Economic Review

Vol. 4, No. 04; 2021

ISSN: 2581-4664

\begin{tabular}{|l|l|l|l|c|}
\hline \hline & Married & 97 & 33.9 \\
\cline { 2 - 4 } & \multicolumn{2}{|l|}{ TOTAL } & $\mathbf{2 8 6}$ & $\mathbf{1 0 0}$ \\
\cline { 2 - 4 } & \multirow{4}{*}{4.} & Educational Level & 4 & 1.4 \\
\cline { 2 - 4 } & SLTA (High School) & 54 & 18.9 \\
\cline { 2 - 4 } & Diploma 3 & 179 & 62.6 \\
\cline { 2 - 4 } & S1 (Bachelor) & 49 & 17.1 \\
\cline { 2 - 4 } & S2 (Master) & $\mathbf{2 8 6}$ & $\mathbf{1 0 0}$ \\
\cline { 2 - 4 } & TOTAL & \multicolumn{2}{|l}{} \\
\hline
\end{tabular}

Validity and Reliability Tests

Table 4. Validity Testing Result

\begin{tabular}{|c|c|c|c|c|c|}
\hline \multicolumn{2}{|c|}{ No. Statement } & Variable & Correlation coefficient & $\begin{array}{c}\text { Critical Value 5\% } \\
(\mathrm{N}=286)\end{array}$ & Validity \\
\hline 1. & $\mathrm{JC} 1$ & \multirow{6}{*}{$\begin{array}{l}\text { Job Crafting } \\
\text { (X) }\end{array}$} & 0.614 & \multirow{6}{*}{1.381} & \multirow{6}{*}{ Valid } \\
\hline 2. & $\mathrm{JC} 2$ & & 0.732 & & \\
\hline 3. & JC3 & & 0.728 & & \\
\hline 4. & $\mathrm{JC} 4$ & & 0.719 & & \\
\hline 5. & JC5 & & 0.599 & & \\
\hline 6. & JC6 & & 0.714 & & \\
\hline 7. & WE1 & \multirow{6}{*}{$\begin{array}{l}\text { Work Engagement } \\
\left(\mathrm{Y}_{1}\right)\end{array}$} & 0.702 & \multirow{6}{*}{1.381} & \multirow{6}{*}{ Valid } \\
\hline 8. & WE2 & & 0.883 & & \\
\hline 9. & WE3 & & 0.867 & & \\
\hline 10. & WE4 & & 0.813 & & \\
\hline 11. & WE5 & & 0.385 & & \\
\hline 12. & WE6 & & 0.851 & & \\
\hline 13. & KK1 & \multirow{6}{*}{$\begin{array}{l}\text { Work satisfaction } \\
\qquad\left(\mathrm{Y}_{2}\right)\end{array}$} & 0.530 & \multirow{6}{*}{1.381} & \multirow{6}{*}{ Valid } \\
\hline 14. & KK2 & & 0.487 & & \\
\hline 15. & KK3 & & 0.579 & & \\
\hline 16. & KK4 & & 0.693 & & \\
\hline 17. & KK5 & & 0.621 & & \\
\hline 18. & KK6 & & 0.659 & & \\
\hline 19. & KP1 & \multirow{8}{*}{$\begin{array}{l}\text { Work performance } \\
\text { (Z) }\end{array}$} & 0.661 & \multirow{8}{*}{1.381} & \multirow{8}{*}{ Valid } \\
\hline 20. & KP2 & & 0.649 & & \\
\hline 21. & KP3 & & 0.795 & & \\
\hline 22. & KP4 & & 0.715 & & \\
\hline 23. & KP5 & & 0.806 & & \\
\hline 24. & KP6 & & 0.756 & & \\
\hline 25. & KP7 & & 0.822 & & \\
\hline 26. & KP8 & & 0.781 & & \\
\hline
\end{tabular}

Source: Processed Primary Data (2021)

The table above shows that all the variables used in this study are valid because they have a correlation coefficient above the critical value of the product-moment correlation, which is 1.381 
International Journal of Business Management and Economic Review

Vol. 4, No. 04; 2021

ISSN: 2581-4664

so that all questions contained in this research questionnaire are valid for further in-depth research. Thus, all indicator items of each variable in this study have met the requirements for further testing.

Table 5. Reliability Testing Result (Alpha)

\begin{tabular}{|c|l|c|c|c|}
\hline No & \multicolumn{1}{|c|}{ Variable } & Variable Item & Alpha Value & Reliability \\
\hline 1. & Job Crafting $(\mathrm{X})$ & 6 & 0.771 & Reliable \\
\hline 2. & Work Engagement $\left(\mathrm{Y}_{1}\right)$ & 6 & 0.886 & Reliable \\
\hline 3. & Work Satisfaction $\left(\mathrm{Y}_{2}\right)$ & 6 & 0.638 & Reliable \\
\hline 4. & Work Performance $(\mathrm{Z})$ & 8 & 0.889 & Reliable \\
\hline
\end{tabular}

Source: Processed Primary Data (2021)

Based on the table above, the alpha value for each respondent's perception variable shows that Job Crafting (X) obtained an alpha value of 0.771, Work Engagement (Y1) obtained an alpha value of 0.886 , job satisfaction (Y2) obtained an alpha value of 0.638 , and work performance (Z) obtained a value of 0.889 . This reliability proves that all indicators of the research variables meet the credibility of Cronbach Alpha where the alpha value is greater than Alpha 0.60.

\section{Confirmatory Factor Analysis}

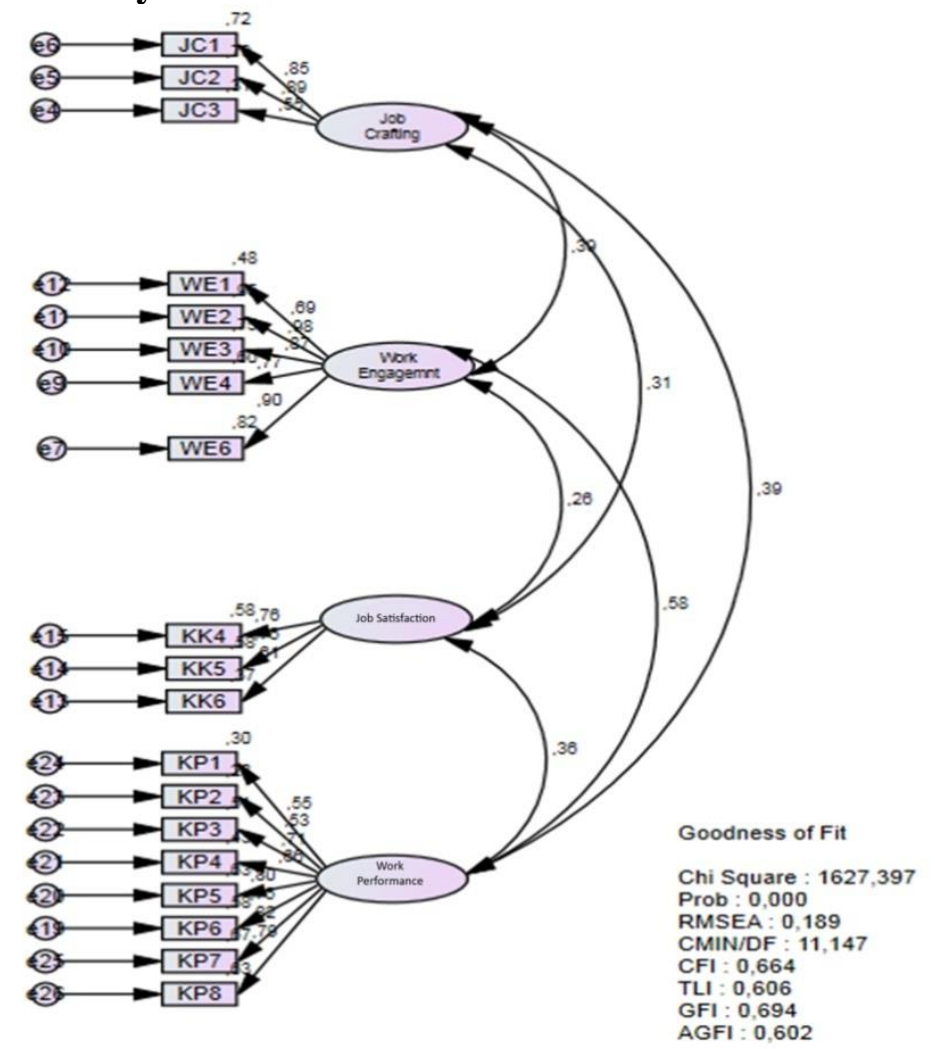

Figure 3. Confirmatory Factor Analysis 
International Journal of Business Management and Economic Review

Vol. 4, No. 04; 2021

ISSN: 2581-4664

Table 6. Loading Factor After eliminating Indicators Estimate

\begin{tabular}{|lll|r|}
\hline & & & Estimate \\
\hline JC3 & $<---$ & Job_Crafting & .554 \\
JC2 & $<---$ & Job_Crafting & .889 \\
JC1 & $<---$ & Job_Crafting & .847 \\
WE6 & $<---$ & Work_Engagement & .903 \\
WE4 & $<---$ & Work_Engagement & .771 \\
WE3 & $<---$ & Work_Engagement & .867 \\
WE2 & $<---$ & Work_Engagement & .977 \\
WE1 & $<---$ & Work_Engagement & .690 \\
KK6 & $<---$ & Job Satisfaction & .608 \\
KK5 & $<---$ & Job Satisfaction & .762 \\
KK4 & $<---$ & Job Satisfaction & .760 \\
KP6 & $<---$ & Work Performance & .759 \\
KP5 & $<---$ & Work Performance & .795 \\
KP4 & $<---$ & Work Performance & .659 \\
KP3 & $<---$ & Work Performance & .713 \\
KP2 & $<---$ & Work Performance & .532 \\
KP1 & $<---$ & Work Performance & .545 \\
KP7 & $<---$ & Work Performance & .816 \\
KP8 & $<---$ & Work Performance & .794 \\
\hline
\end{tabular}

Based on the results shows in the table above, all indicators have met the requirements to be included in the next data processing because all loading factor values are $>0.5$.

\section{Goodness of Fit}

Table 7. The goodness of Fit Criteria

\begin{tabular}{|l|c|c|c|}
\hline \multicolumn{1}{|c|}{ The goodness of Fit } & Cut off Value & Result & Model Evaluation \\
\hline Chi-Square & $<240.995$ & 155.782 & Good \\
\hline Probability & $\geq 0.05$ & 0.080 & Good \\
\hline RMSEA & $\leq 0.08$ & 0.064 & Good \\
\hline GFI & $\geq 0.90$ & 0.930 & Good \\
\hline AGFI & $\geq 0.90$ & 0.963 & Good \\
\hline CMIN/DF & $\leq 2.00$ & 1.087 & Good \\
\hline TLI & $\geq 0.90$ & 0.960 & Good \\
\hline CFI & $\geq 0.90$ & 0.905 & Good \\
\hline
\end{tabular}

Source: Processed Primary Data (2021) 
International Journal of Business Management and Economic Review

Vol. 4, No. 04; 2021

ISSN: 2581-4664

Based on the table above, it shows that the results of the measurement model analysis obtain the value of chi-square $=155.782$ at probability $=0.080$ classified as fit. Meanwhile $2 / \mathrm{df}=1.087$; RMSEA=0.064; GFI $=0.930$; TLI $=0.960 ; \mathrm{AGFI}=0.963$; and $\mathrm{CFI}=0.905$ has met the criteria and the value indicates fit. In general, by using the Goodness of Fit test, it can be concluded that the existing measurement model has met the fit criteria so that the outputs from this model can be used as research findings related to the relationship between indicators and their respective constructs.

\section{Hypothesis Result and Discussion}

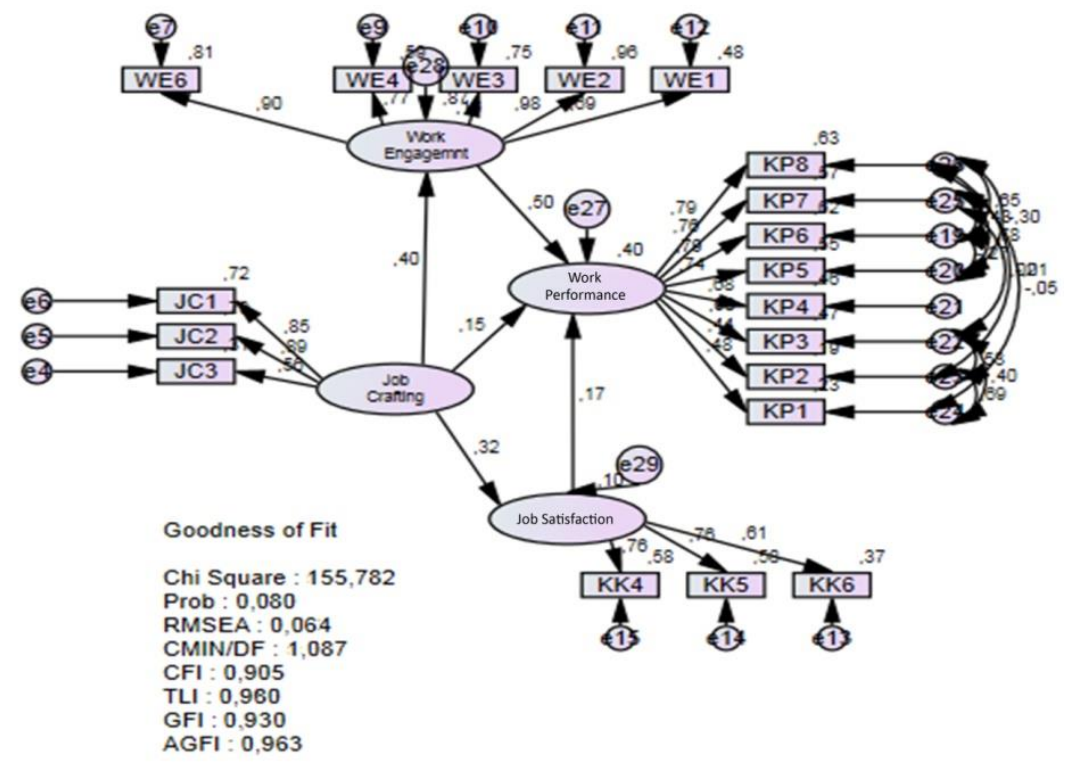

Figure 4. SEM Testing Result

The figure above provides the results as follows.

Table 8. Regression Weight

\begin{tabular}{|lll|cccc|}
\hline & & & Estimate & S.E. & C.R. & P \\
\hline Work Engagement & $<---$ & Job Crafting & 0.397 & 0.097 & 5.563 & 0.000 \\
Job Satisfaction & $<---$ & Job Crafting & 0.317 & 0.076 & 3.939 & 0.000 \\
Work Performance & $<---$ & Job Crafting & 0.149 & 0.070 & 2.222 & 0.026 \\
Work Performance & $<---$ & Job Satisfaction & 0.168 & 0.073 & 2.558 & 0.011 \\
Work Performance & $<---$ & Work Engagement & 0.503 & 0.050 & 7.781 & 0.000 \\
\hline
\end{tabular}

Source: Processed Primary Data (2021)

Based on the results of SEM analysis in the table above, it can be formulated:

Work Engagement $=0.397$ Job Crafting

Job Satisfaction $=0.317$ Job Crafting 


\section{International Journal of Business Management and Economic Review}

Vol. 4, No. 04; 2021

ISSN: 2581-4664

Work Performance $\quad=\quad 0.149$ Job Crafting +0.168 Job Satisfaction +0.503

Work Engagement

By seeing the result of the structural model Testing above, the answer of the research hypothesis is explained as follows.

Hypothesis $1:$ Job Crafting affects Work Engagement

The effect of job crafting on work engagement obtains a CR value of 5.563 with a significance level of 0.000 . Thus, it reveals that job crafting has an effect on increasing work engagement. The effect of job crafting on work engagement is 0.397 or $39.7 \%$. This is proven by the improvement of job crafting in providing a positive and significant impact on increasing work engagement.

Hypothesis 2 : Job Crafting affects Job Satisfaction

The effect of job crafting on job satisfaction obtains a CR value of 3.939 with a significance level of 0.000 . Thus, it explains that job crafting has an effect on increasing job satisfaction. The effect of self-efficacy on job satisfaction is 0.317 or $31.7 \%$. This indicates that the higher level of job crafting is, the more job satisfaction will increase.

Hypothesis 3 : Job Crafting affects Work Performance

The effect of job crafting on work performance obtains a $C R$ value of 2,222 with a significance level of 0.000 . Thus, it describes that job crafting has an effect on increasing work performance. The effect of job crafting on work performance is 0,149 or $14.9 \%$. This indicates that the higher level of job crafting is, the more work performance will increase.

Hypothesis 4 : Job Crafting affects Work Performance through Work Engagement

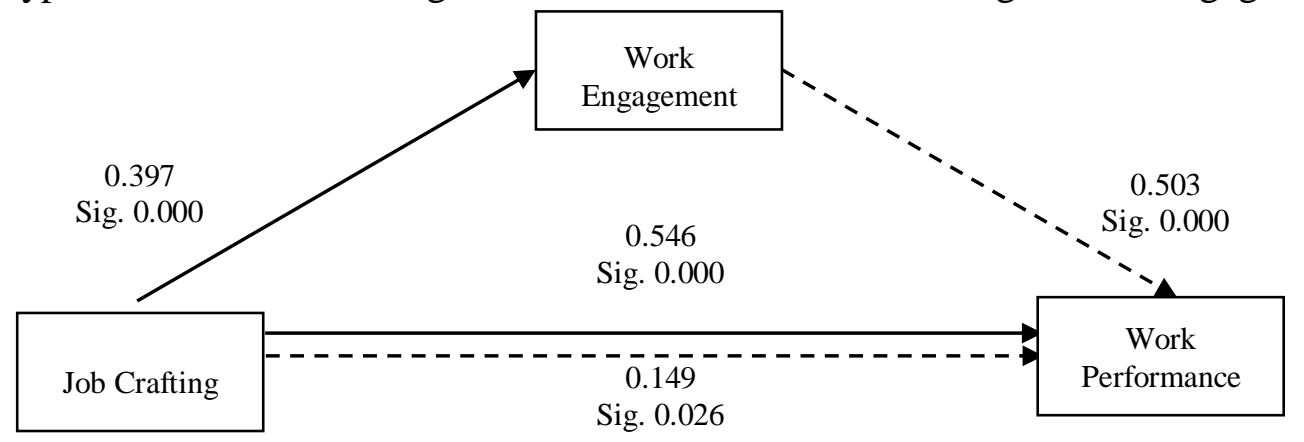

Figure 5. Mediation Effect Testing of Hypothesis 4

Based on the picture above, it is found that the path coefficient between job crafting and work engagement shows a path coefficient value of 0.397 , while the path coefficient of work engagement on employee performance is 0.503 . The path coefficient between job crafting and work performance is 0.149 . Because the direct effect of job crafting on work performance, job crafting on work engagement, and work engagement on work performance is significant at 5\%, it 


\section{International Journal of Business Management and Economic Review}

Vol. 4, No. 04; 2021

ISSN: 2581-4664

can be concluded that work engagement acts as a variable that mediates the relationship between job crafting on work performance. Here, work engagement taking part as partial mediation.

Hypothesis 5 : Job Crafting affects Work Performance through Work Engagement

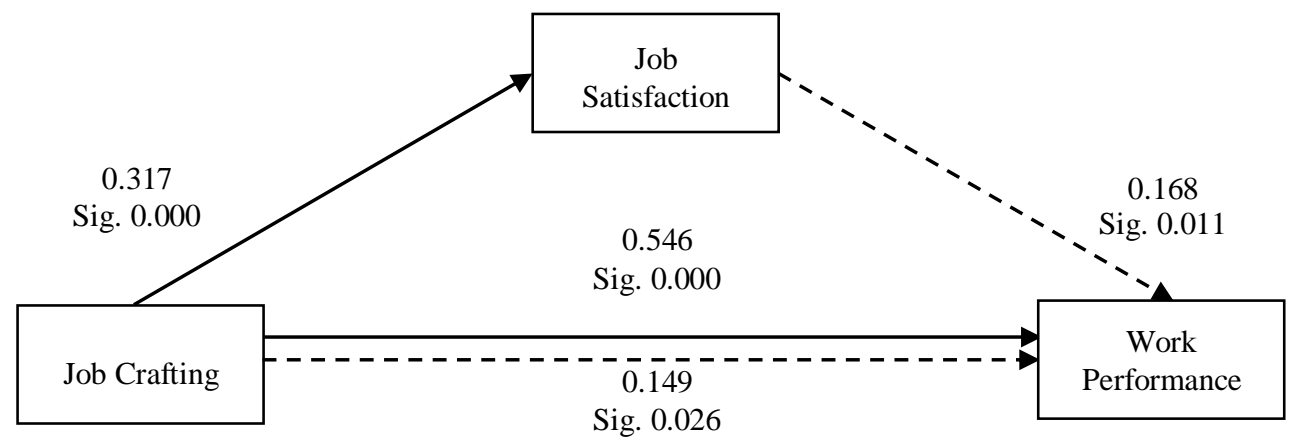

Figure 6. Mediation Effect Testing of Hypothesis 5

Based on the figure above, it is found that the path coefficient between job crafting and job satisfaction shows a path coefficient value of 0,317 , while the path coefficient of job satisfaction on work performance is 0,168 . The path coefficient between job crafting and work performance is 0.149 . Because the direct effect of job crafting on work performance, job crafting on job satisfaction and job satisfaction on work performance all three are significant at $5 \%$, it can be concluded that work engagement acts as a variable that mediates the relationship between job crafting on work performance. Here, job satisfaction taking part as partial mediation.

Mediation Type of Hypothesis 4 and Hypothesis 5 Models

Meanwhile, the conclusion of mediation testing in this study described in the following table:

Table 9. Effect Result Comparison

\begin{tabular}{|c|l|c|c|c|c|}
\hline No & \multicolumn{1}{|c|}{ Hypothesis } & $\begin{array}{c}\text { Direct effect } \\
\mathrm{X} \text { to Y }\end{array}$ & $\begin{array}{c}\text { Direct effect } \\
\mathrm{X} \text { to Z }\end{array}$ & $\begin{array}{c}\text { Indirect effect } \\
\mathrm{X} \text { to Z }\end{array}$ & Desc. \\
\hline 1. & $\begin{array}{l}\text { Testing the effect of job } \\
\text { crafting variable }\left(\mathrm{X}_{1}\right) \text { on work } \\
\text { performance variable (Z) } \\
\text { through work engagement } \\
\text { variable (Y) }\end{array}$ & $\begin{array}{c}0.397 \\
(0.000<0.05)\end{array}$ & $\begin{array}{c}0.149 \\
(0.026<0.05)\end{array}$ & $\begin{array}{c}0.546 \\
(0.000<0.05)\end{array}$ & $\begin{array}{c}\text { Partially } \\
\text { mediating }\end{array}$ \\
\hline 2. & $\begin{array}{l}\text { Testing the effect of job } \\
\text { crafting variable }\left(\mathrm{X}_{1}\right) \text { on work } \\
\text { performance variable (Z) } \\
\text { through job satisfaction } \\
\text { variable (Y) }\end{array}$ & $\begin{array}{c}0.317 \\
(0.011<0.05)\end{array}$ & $\begin{array}{c}0.149 \\
(0.026<0.05)\end{array}$ & $\begin{array}{c}0.546 \\
(0.000>0.05\end{array}$ & $\begin{array}{c}\text { Partially } \\
\text { mediating }\end{array}$ \\
\hline
\end{tabular}

Based on the table above, a brief conclusion can be drawn that testing effect of job crafting variable $(\mathrm{X})$ on work performance variable $(\mathrm{Z})$ through work engagement variable $(\mathrm{Y})$ shows the 


\section{International Journal of Business Management and Economic Review}

Vol. 4, No. 04; 2021

ISSN: 2581-4664

correlation of partial mediating, which means job crafting is also able to directly impact the work performance without going through work engagement.

Meanwhile, testing the effect of job crafting variable $(\mathrm{X})$ on work performance variable $(\mathrm{Z})$ through job satisfaction variable (Y) shows the correlation of partial mediating, which means job crafting is also able to directly impact the work performance without going through job satisfaction.

\section{CONCLUSION}

From the result and analysis, we can conclude that job crafting affects work engagement, job crafting affects job satisfaction, job crafting affects work performance, job crafting affects work performance through work engagement, and job crafting affects work performance through job satisfaction. Work engagement and job satisfaction act as partial mediators in the model. These findings, academically illustrates that the model studied has been tested and verified, that for models of improving work performance, the function of increasing job crafting is very necessary to be carried out, so that it can affect work engagement and job satisfaction which will result in increased work performance. This finding has implications for the realm of science management so that further researchers can develop this tested work performance improvement model by adding new variables such as talent management and innovative culture. Some suggestions are provided from the practical analysis as follows.

1. On the work engagement variable, it was found that every employee did not have an attachment to the assigned work so some employees didn't follow every activity that was held by the LAN RI. This matter must get full attention from the LAN RI to anticipate a worse situation in the form of not achieving various targets set by the organization.

2. At least there are three indicators of job satisfaction variables whose acceleration still needs to be improved and receive special attention from the organization, namely skills (creative) at work, promotion (career) opportunities for all employees, and co-workers association both inside and outside the work environment on LAN RI.

3. Practical suggestions that can be given to the Head of LAN RI that the results of this study can be used as a reference in achieving maximum employee performance by developing job crafting among employees through the existence of high work engagement and increasing job satisfaction among all employees.

\section{REFERENCES}

Agusniwar, I., Azis, N., \& Darsono, N. (2017). Pengaruh Kompleksitas Tugas Dan Locus Of Control Terhadap Kinerja Karyawan Dan Dampaknya Pada Kinerja Pt. Bank Rakyat Indonesia Cabang Meulaboh. Jurnal Magister Manajemen, 1(1), 16-24.

Albana, H. (2019). The Effect of Job Crafting on Employee Performance Mediated by Work Engagement at PT. Lamong Bay Terminal, Surabaya. Jurnal Ilmu Manajemen, 7(1), 210-219.

Baron, R. M., \& Kenny, D. A. (1986). The Moderator-Mediator Variable Distinction in Social Psychological Research: Conceptual, Strategic, and Statistical Considerations. Journal of Personality and Social Psychology, 51(6), 1173-1182.

Damayanti, R., Hanafi, A., \& Cahyadi, A. (2018). The Effect of Job Satisfaction on Employee Performance (Case Study of Non-Medical Employees at Siti Khadijah Islamic Hospital 


\section{International Journal of Business Management and Economic Review}

Vol. 4, No. 04; 2021

ISSN: 2581-4664

Palembang). JEMBATAN - Jurnal Ilmiah Manajemen Bisnis Dan Terapan, 15(2), 75-86. https://doi.org/https://doi.org/10.29259/jmbt.v15i2.6655

Gomes, F. C. (2003). Manajemen sumber daya manusia. Yogyakarta: Andi.

Hooff, N. van. (2016). The impact of job crafting on job performance: the mediating effect of participation in HRD and the moderating role of age. Tilburg University.

Hughes, R. L., Ginnett, R. C., Curphy, G. J., \& Izzati, P. I. (2012). Leadership: memperkaya pelajaran dari pengalaman $=$ leadership : enhancing the lessons of experience (7th ed.). Jakarta: salemba Humanika.

Kuijpers, E., Kooij, D., \& Woerkom, M. Van. (2019). Align your job with yourself: The relationship between a job crafting intervention and work engagement, and the role of workload. Journal of Occupational Health Psychology, 25(1), 1-53. https://doi.org/10.1037/ocp0000175

Luthans, F. (2013). Organizational Behavior An Evidence-Based Approach (8th ed.). New York: Mc Graw Hill.

Newstrom, J. W., \& Davis, K. (2002). Organizational Behavior: Human Behavior at Work. New York: McGraw-Hill.

Perrin, T. (2003). Working Today: Understanding What Drives Employee Engagement. United States.

Petrou, P., Demerouti, E., \& Schaufeli, W. B. (2015). Job crafting in changing organizations: antecedents and implications for exhaustion and performance. Journal of Occupational Health Psychology, 20(4), 470-480. https://doi.org/https://doi.org/10.1037/a0039003

Qodariah. (2019). Description Analysis of the Effect of Work Engagement on Employee Performance: Ability (A), Effort (E), Support (S) PT Surveyor Indonesia. Journal of Management \& Business, 2(1), 53-64. https://doi.org/https://doi.org/10.26877/sta.v2i1.4033

Robbins, S. P., \& Judge, T. A. (2017). Essential of Organisational Behaviour (14th ed.). New Jersey: Pearson.

Saks, A. M. (2006). Employee engagement: Antecendents and consequences. Journal of Managerial Psychology, 21(7), 600-619.

Schaufeli, W. B., Bakker, A. B., \& Salanova, M. (2006). The measurement of work engagement with a short questionnaire: A cross-national study. Educational and Psychological Measurement, 66(4), 701-716. https://doi.org/10.1177/0013164405282471

Tims, M., Bakker, A. B., \& Derks, D. (2013). The Impact of Job Crafting on Job Demands, Job Resources, and Well-Being. Journal of Occupational Health Psychology, 18(2), 230-240. https://doi.org/10.1037/a0032141

Wagner, J. A., \& Hollenbeck, J. R. (2015). Organizational Behavior Securing Competitive Advantage (2nd ed.). London: Routledge.

Wijaya, I. K. (2018). The Effect of Job Satisfaction on Employee Performance CV. Sanomas Hill. Agora, 6(2), 1-5.

Wingerden, J. van, \& Poell, R. F. (2017). Employees' perceived opportunities to craft and in-role performance: The mediating role of job crafting and work engagemen. Front Psychol, 1-9. https://doi.org/https://doi.org/10.3389/fpsyg.2017.01876 